\title{
The Woman Empowerment Model through Entrepreneurship in Depok and Bogor
}

\section{Hasanah $^{1}$ and Nurul Sriminarti ${ }^{2}$}

\author{
${ }^{1}$ Universitas Muhammadiyah Jakarta, hasanah.umj@gmail.com \\ ${ }^{2}$ Universitas Muhammadiyah Jakarta, nurulsriminartii@gmail.com
}

\begin{abstract}
The role of woman in the field of entrepreneurship increases rapidly because, in this era of openness, the opportunities for females are widely open. By means of females, participating in economic activities provide a good condition for the Indonesian economy. The purpose of this research is to create a woman empowering model through entrepreneurship in the region of Depok and Bogor. The research method used is a survey. Survey research is a study which is conducted on large and small populations, but the data studied are the data from the samples taken from both the populations, so that the relative activities, distribution, and the relationship between sociological and psychological variables can be founded. The result obtained from the research is the creation of a woman empowerment model through entrepreneurship in producing Nata de Aloe Vera product which is highly competitive with similar products produced by craftsmen industry in other areas. Through all the time, the sales and marketing conducted are only based on a simple traditional way. A group of craftswoman produces nata de aloe vera every day, but they only make it in small quantity. They also produce in large quantity if there are orders for big parties such as for wedding party, office events and other special events. The output of this research is a journal, HKI.
\end{abstract}

Keywords: woman, entrepreneurship, aloe vera, nata de aloe vera

\section{Introduction}

The female role in developing the economy of a country plays a very important role in building and improving the production capability of a state with its diversity. Currently, a woman as an entrepreneur should be involved through entrepreneurship development. An Indonesian woman has contributed a lot in improving the competitiveness of small and medium enterprises (SMEs) sector as well as creating job opportunities and reducing the impact of poverty in Indonesia. Therefore, in empowering woman as a business actor is by providing them the access and opportunity as wide as possible in competing with other entrepreneurs who are mostly conducted by males. The participation of woman as an entrepreneur is very important and is expected in the presence of limited employment opportunities. The woman is often seen as a weak creature who cannot contribute to the economy matters, but this kind of view is totally wrong. Currently, the existing small and medium enterprises (SMEs) are mostly run by women, so it can be said that women are very instrumental in promoting people's economy through small and medium enterprises (SMEs).

Although the role of a woman is very important in increasing revenue, the fact is there is no acknowledgment in implementing entrepreneurship in the community. Many small and medium enterprises (SMEs) that are undertaken by women cannot develop well. This is because they lack capital assistance which becomes the problem. They do not know how to market the products they produce. This condition needs support from many elements so that women entrepreneurs can succeed in carrying out their business because their potential is very essential to build and improve the economy of society in particular and also the state. Indonesian women who own their business are important contributors to national economic growth. The Asia Foundation reports that women have $35 \%$ of small and medium enterprises (SMEs) in Indonesia. In the Asia/Pacific region, Indonesia ranks top in terms of the number of women as SMEs owners, although one of the reasons for the high entrepreneurship among women can be attributed to low employment in the formal sector for women. In other word, women entrepreneurs are more likely to be found in the small and micro- mediumsized enterprises compared to large-scale enterprises. 
The role of females in the field of entrepreneurship increases rapidly because, in this era of openness, the opportunities for females are open widely. By means of females, participating in the economic activities provide a good condition for the Indonesian economy. The more the woman participates in increasing the industry, the more job opportunities are available. Thus, it can reduce unemployment especially for housewives who do not work outside, and this job opportunity will improve their family income.

In this research, the researcher explores the problem of woman empowerment through entrepreneurship by managing aloe vera which is easy to be found around Depok and Bogor, so it can increase the woman's knowledge, skill, and gaining. This entrepreneurial election is based on the state of the environment that can obtain the raw materials of aloe vera easily. Aloe vera is a plant that has many perks. Seen from the cultivation, the plant is easy to breed and does not require any difficult maintenance, while viewed from the benefits, aloe vera can be the raw materials for medicine and cosmetics and it also can be made for food and beverages like aloe vera jam, aloe vera flour, and nata de aloe vera. Therefore, the aloe vera that grows in the population can be used as a commodity that can increase the household income by empowering women. Women entrepreneurs in the home industry level who manufacture nata de aloe vera in Depok and Bogor, have a group of housewives who do not work outside. Therefore, they spend their free time to produce nata de aloe vera. They do it to increase income to meet daily needs. Most of the producers of these businesses are women, start from taking aloe vera leaves, cleaning, processing, packaging, and marketing of their products. The strategy of marketing is still used a conventional way, which is by finding customers from around the area by selling their products at shops or small stalls or they are also taking orders such for celebration, gathering or other meeting events. The demand that comes in from the consumers who have consumed their product. However, they have yet to use the great opportunities they have because of the lack of capital, so they cannot handle all the orders. There many obstacles faced by them in developing their business in the future. They still lack capital assistance, lack of information about marketing, managerial, and the information technology aspects. The processing of nata de aloe vera is done in small scale industries and it uses simple processing technology, so the result is not maximal. In general, they do not run the business by using neat bookkeeping, rather, they still conduct it in a traditional way and so that they get the rough draft of it. Therefore, the objectives of this research are: a) the potential and opportunities of women and housewives are still maximizing the resources of processed aloe vera, $b$ ) to direct in making business proposal in obtaining business assistance funds, c) to direct the right marketing strategy to the home industry, d) to direct the importance of technology knowledge in business development.

Entrepreneurship is the courage to seek the fulfillment of the necessities of life, on the basis of the ability to take advantage of all the potential to produce something beneficial to himself and others. According to (Sanusi, 1994) entrepreneurship is a value embodied in behavior that is used as resources, driving force, goals, strategies, tips, processes, and business results. While according to (Zimmerer, 1996), entrepreneurship is a process of applying creativity and innovation in solving problems and find opportunities to improve business life. Moreover, according to (Siswanto, 1989), entrepreneurship is everything that is important about an entrepreneur itself that is people who have the nature of hard work and sacrifice, concentrate all the power and dare to take risks to realize the idea. Based on the above understandings, the roles of entrepreneurs are:

a. As one of the ways out or the alternative way to solve the problem of employment (reduce unemployment)

b. As a form of involvement in building the national economy without burdening the government and society.

c. As a form of increasing productivity of the production factors

The characteristics of entrepreneurship according to (Suryana, 2003) include:

a. Having the courage to have the power of creation.

b. Dare to take risks 
c. Having passion and willpower

d. Having the right analysis

e. Not consumptive

f. Having a leader's soul

g. Orienting to the future

The sectors in the business in relation to the entrepreneurship can be divided into two, namely:

a. Formal Sector. This is an activity that is managed in such a way so that it has a permanent activity as the hope of its management. The formal economic sectors that can be cultivated include:

1) Industry such as large industry, medium industry, small industry, handicraft industry, and the tourism industry.

2) Trade, these trades can involve domestic trade, foreign trade or international trade, as well as wholesalers, middle traders, and small traders.

3) Services and Transportation, which includes intermediary traders, lenders or banks, transport entrepreneurs, hotel and restaurant entrepreneurs, business travel agents, insurance entrepreneurs, warehouses, workshops, cooperatives, clothing and so on.

4) Agriculture, which includes agriculture, plantation and forestry, fisheries, and animal husbandry.

5) Field of Mining and Energy, covering the fields of petroleum and natural gas.

6) Other businesses in the form of a company, incorporated, or non-legal entities.

b. Informal Sector. It is a side business activity that is usually not in the form of companies, and usually in a form of a home industry. Some kind of the informal economic sectors are:

1) Trade, meaning as a small trader or retailer.

2) Home industry, including craftsmen, processing of plantation products, processing of agricultural products, processing of fishery products, processing of livestock, and processing of forestry products.

3) Services, including intermediary trades, transportation, food stalls, workshop, travel agency/travel, clothing/tailor, and so forth.

4) Agriculture, including food crop agriculture, small plantations, terrestrial fisheries, and livestock, and so forth.

5) Other business that is not in the form of company

The entrepreneurship process includes the following stages (Alma, 2007):

a. Innovation process. Innovation is a very prominent feature of entrepreneurship and is a key function in the entrepreneurial process. Innovation is a process of turning opportunities into marketable ideas. Innovation is more than just a good idea. A pure idea plays an important role, the creative mind develops it into a valuable idea. Factors that encourage innovation are:

1) The desire to achieve

2) The nature of curiosity

3) The desire to bear the risk

4) Education

5) Experience

b. The trigger processes. Some factors that encourage someone to enter the business world is the dissatisfaction of existing jobs, the occurrence of the termination of employment (PHK), the driving factor of age, the courage to bear the risk, high commitment to the business.

c. The implementation processes. There are some factors that drive the implementation of a business which is the total mental preparation in running the business, the existence of manager as the conductor, the commitment to business and the vision of the future to achieve success.

$\mathrm{d}$. The growth processes. The growth process is driven by organizational factors, such as the existence of a compact team in running the business, the steady strategy, the existence of good organizational structure and culture, and the existence of superior products. 
In general, there are some stages in the entrepreneurship. According to Zimmerer in (Suryana, 2003), they are as follows:

a. Stage of starting a business

b. Stage of conducting business

c. Stage of maintaining business

d. Stage of developing a business

According to Zimmerer in (Suryana, 2003), in running a business, an entrepreneur must have entrepreneurial attitudes, which are:

a. Discipline. In carrying out the activities, an entrepreneur must have a high discipline. The meaning of the word discipline itself is the precision of entrepreneurial commitment to the task and work. The precision is comprehensive, namely the accuracy of the time, quality of work, work system and so forth.

b. High Commitment. Commitment is a consensus on something made by a person, both to himself and to others. In carrying out the activities, an entrepreneur must have a clear commitment, directed and progressive (progress-oriented).

c. Honest. Honesty is a moral foundation that is sometimes overlooked by an entrepreneur.

d. Creative and Innovative. To win the competition, an entrepreneur must have high creativity. Creativity power should be based on advanced thinking, filled with new ideas that are different from the products that have been there so far in the market.

e. Independent. Somebody can be called to be "independent" if the person can do the desire well without the dependence of other parties in making decisions or acting, including sufficient life, without any dependence with other parties.

f. Realistic. Someone can be called realistic if the person is able to use facts/realities the rational base of thought in every decision and action/action.

According to Suryana (2003), there are several factors that cause entrepreneurs to fail in running a new business, they are:

a. Not competent in managerial. Not being competent or not having in the skills and knowledge to manage a business is a major factor that makes the company less successful.

b. Less experienced. Less experienced both in the ability to coordinate, to manage human resources, and to integrate the operational of the company.

c. Lack of knowledge in controlling finances. To gain success, the most important factor in maintaining the company cash flow by managing the outcome and income carefully.

d. Failure on planning. Planning is the starting point of activity, once failed; it will bring difficulty in running the business.

e. Non-strategic location. The strategic location is a one-factor measurement of business success. Non-strategic locations can cause companies to operate less efficiently.

f. Lack of equipment supervision. Close supervision relates to efficiency and effectiveness. Fewer supervision results in inefficient and ineffective usage of tools.

g. Less initiate in running a business. A half-hearted attitude toward the effort will result in a failed effort and failure. With a half-hearted attitude, the possibility of failure can be great.

h. Inability to make the transition/entrepreneurial transition. Entrepreneurs who are less prepared to face and make changes will not become successful entrepreneurs.

According to Novian (2010), the empowerment of woman is the effort of the woman to gain access and control to the resources, economy, politics, social, culture, so that woman can arrange herself and increase her confidence to be able to participate actively in solving problems, ability, and selfconcept. Woman's empowerment is both a process and a goal. As a process, empowerment is an activity to strengthen the power and empowerment of weak groups in society. As a goal, empowerment refers to the circumstances or outcomes that are to be achieved by social change.

There are several objectives of the woman empowerment program. They are: 
a. Increasing the quality of a woman's resources in various sector and sub-sector and institutional and non-institutional activities that prioritize the improvement of a woman's capability and professionalism or expertise.

b. Realizing gender sensitivity, awareness of the entire community, policy makers, decision makers, planners, and law enforcement and renewal of legal products that have socio-cultural values and gender-sensitive justice.

c. Optimizing coordination and integration in the management of woman's empowerment covering aspects of planning, implementation, controlling, monitoring, evaluation, and reporting

Sunaryanto (2007) explained that the influence of geographical location on the successful development of SMEs in a region can become a defender potential local economy and the development of IT is certainly also can be utilized to further promote SME.

Lestari (2014) revealed that the wood carving handicraft value chain consists of; Supplier, Manufacturer of wood carving products, Trader or Exporter and final Consumer. Constraints faced by crafters at the upstream level are the lack of sources of production of wood supply raw materials originating from the Bali and lack of capital assistance. While the obstacles in the downstream are lack of support of the Department of Industry and trade and the Cooperative Service (Government) in the marketing process and showcase of products of wood carving in Bali Province and National level.

Resmi (2014) stated that most of women's businesses are engaged in the category of home-based industries, business groups, and small businesses that utilize self-sufficiency such as the industry of making the smoked fish. This industry is a hereditary effort, and it is able to survive until now even though the profit they get is limited to the fulfillment of the necessities of life day-to-day, school fees, and medical expenses. It is necessary to encourage and motivate the entrepreneurship of smoked fish, thus minimizing the number of unemployed and the number of poor families.

Natsir (2013) found two empirical findings. First, Aloe vera leaf extract has a very real effect (P > $1 \%$ ) on power Inhibitory growth of Staphylococcus aureus. Second, at concentrations of $0 \%, 25 \%$, $30 \%$, and $35 \%$ showed inhibitory power of $0 \mathrm{~mm} 1.36 \mathrm{~mm}, 1.6 \mathrm{~mm}$, and $0.94 \mathrm{~mm}$.

\section{Research Methodology}

The population in this study is a cottage industry that empowers women and housewives through entrepreneurship in producing Nata de aloe vera in Depok and Bogor. The sample in this study is a group of home-based industry producers from aloe vera (aloe vera) which is processed into nata de aloe vera (food) which is incorporated in:

a. KWT PRIMAJAYA MANDIRI which was located at Sasak Panjang Parung Bogor. It consisted of the composition of the board as follows:

Chairman: Yanti Safitri

Vice Chairman: Etty Hastuti

Secretary: Tuti

Treasurer: Ella

Members: Jumiati, Sawiyah, Nina Sutiana, Ruminah, Jejen, Mariyam, Lasinah, Nuraida, Suryanti, Awalinah

b. KWT Sri Jaya Mandiri, which was located at Duren Seribu Rt.003 Rw.01, Kelurahan Duren Seribu, Bojongsari, Depok. Consisting of :

Chairman: Nurrahmat

Vice Chairman: Yayah

Secretary: Leli

Treasurer: Zubaedah

Members: Wahyudi, Erni, Ahma E.

In this study, the characteristic of the research used is a survey. According Sugiyono (2010), survey research is a study which is conducted on large and small populations, but the data studied are the 
data from the samples taken from both the populations, so that it can be found the business opportunities and the relationship between sociological and psychological variables.

While the method used is Action Research (Action research), including participatory research, collaborative investigation, emancipatory research, action learning, and contextual action research. As for its simple understanding, action research is "learning by doing" - a group of people identifying a problem, doing something to overcome it, see how successful their business is, and if not satisfied, then try again. Action research involves the active process of participating in organizational change situations whilst conducting research.

\section{Result and Discussion}

Based on the results of research, which was conducted by researchers by visiting the object of this study, that is the producer of food and beverages made from aloe vera. The typical physical characteristics of aloe vera and easy to innovate make choice for the lovers this ornamental plant, therefore, aloe vera can serve as a business opportunity for easy-to-manage business actors, whether household scale, small industry, medium, and large.

From the results of research conducted through the field research, those local governments have helped residents in the area of Depok and Bogor in providing counseling, training, and assistance in entrepreneurship by helping the capital needed to become an independent entrepreneur. However, the aid seems to have not been fully utilized and has not been utilized optimally by the people in the region.

Industry players in Depok and Bogor areas are mostly women or housewives. They process aloe vera into food and drinks. But the processing is still with a traditional and simple way, as well as with the marketing. The products produced in Depok and Bogor region which are based on aloe vera are Nata de aloe vera as a drink, dodol, and jam as a food.

Although the products they produce are common among the public. But at least they succeed in making the commodities that grow around them can be useful. Moreover, it increases the income of the community. Despite the fact that there are men who are employed there, they need to be emphasized is the program successfully empowers women.

The Aloe vera they need to produce nata de aloe vera as much as 100 cups of size $240 \mathrm{ml}$ is $50 \mathrm{~kg}$. It takes a lot of materials because they will shrink after the cooking process. To keep the quality, they use only large aloe vera in which the meat is thicker and chewier than the small aloe vera. If the raw materials are not available, they look for its Tangerang which also contains many aloe vera.

The entrepreneurship group of KWT Primajasa Mandiri and KWT Sri Jaya Mandiri, marketed the product, initially only to the surrounding areas. By having the help of capital government, they can promote their product to some places like:
a. Cooperatives
b. The small and medium shops
c. Stalls in a residential neighborhood
d. Offices
e. Outlet
f. School canteen

The example is such the KWT Sri Jaya Mandiri group, as the craftsmen industry which often get orders from office or weddings events. They work with consumer providers at these events. The marketing they do is still limited to offer it by displaying its products.

Products produced by home industry craftsmen for Nata de Aloe vera are highly competitive with similar products produced by home industry craftsmen in other regions. The marketing and sales done so far were only based on simple traditional ways. The group of craftswoman makes and produces nata de aloe vera every day, but the quantity is not that much. But if there is a big order for nata de 
aloe vera, then they will produce or make in large quantities or in accordance with the order. And usually, the order is for events, whether weddings, office events, or events that require special orders. The obstacles above, make nata de aloe vera producers deal with the problem of production and marketing. The production is unstable, even once the group is a vacuum in the production of nata de aloe vera because there is no incoming order and the product of inventory is yet to be ready. Lack of marketing aspect makes the products they produce do not last long in sales. At the beginning of the production of nata de aloe vera, their products were highly sold and very popular by the public, but it did not last long. As time went by, when they produced it, the sales decreased. Finally, over time, they experienced the process of product selling decreased and did not develop well. As this group did not update the development of technology, they could not compete for their product with other product (food and beverage) processed from other basic ingredients.

Other obstacles are also identified which is in the lack of capital in providing more sophisticated equipment. The equipment needed is the modern nata de aloe vera making machines and storage areas that can store the product. If it is stored in the cooling machines, the product will not quickly damage, and it can last for a longer period of time (for example for a week). All the main equipment need capital to buy it. Meanwhile, the woman there is the only housewife who has no job and no income. It will take a big effort to buy that equipment. Therefore, the nata de aloe vera home industry craftswomen need capital assistance either from the local government or from other institutions in improving the resulting product. Barriers also come from the marketing of nata de aloe vera products. The marketing is still in a very simple way of marketing which is from mouth to ear. So, the public recognition of nata de aloe vera products is still very less. They do not understand marketing in the more modern trade. Indeed, there are many ways used for marketing their products in order to be competitive for example by using social media, internet, banners, brochures, etc. These ways can introduce their products so that they can be known by the public. The public will be more aware of its product and its benefits.

This research tries to make an appropriate model which can be used by nata de aloe vera home industry craftswoman; that is "the Model of woman empowerment through entrepreneurship in Depok and Bogor". The purpose of this model is to help women or housewives to become independent entrepreneurs and succeed in producing aloe vera food of nata de aloe vera. This can improve the economic life of her family so that it will impact on the increase of national income. The model to be applied is as follows:

Figure 1 models of the home industry of nata de aloe vera products

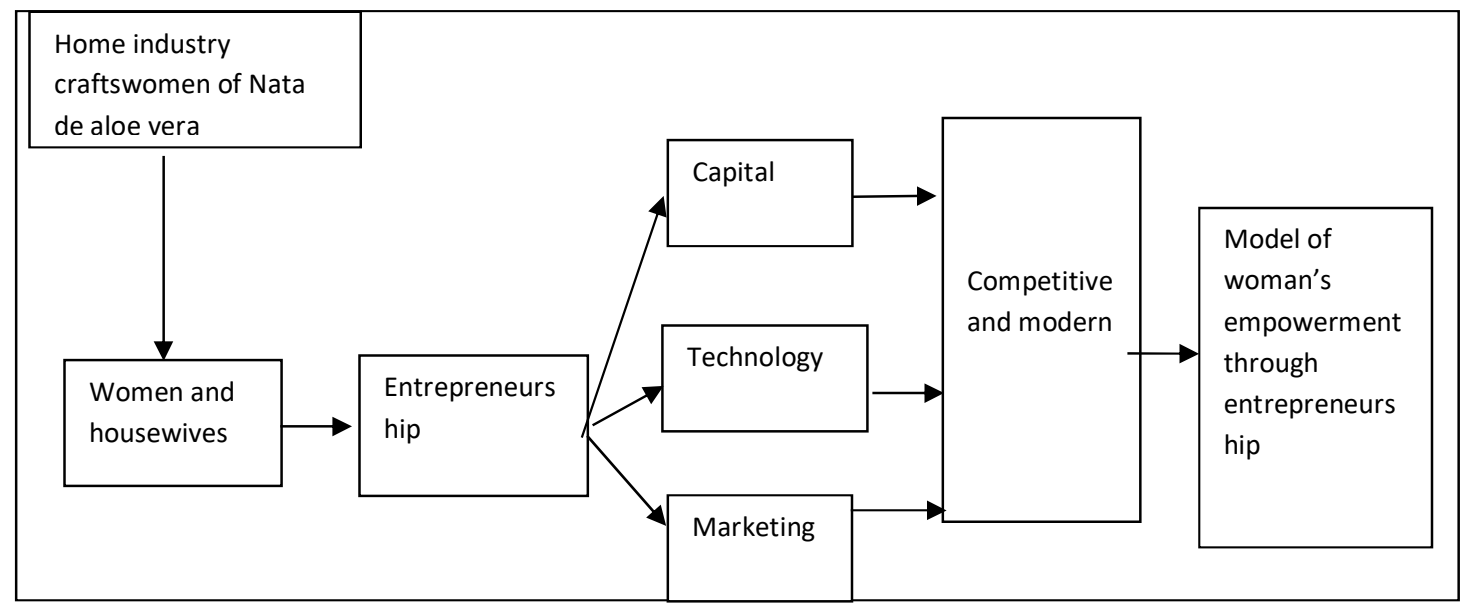

In running a business, whether it is small, medium, or large business; It must have an analysis in each activity. In order to predict what we should do or what we will do and how we do it. Below is SWOT 
analysis in woman empowerment through entrepreneurship in Depok and Bogor region, with home industry craftswoman of nata de aloe vera.

a. Strength

1) The availability of raw materials

2) The availability of labor

3) The availability of land or area to grow aloe vera plant

4) The strong family kinship attitude

5) The help from local government

6) Weakness

b. The disadvantages are:

1) The potential of women and housewives has yet to be fully utilized

2) A small amount of capital

3) Lack of human resources

4) The technology used is still simple

5) The marketing is still traditional and simple

c. Opportunity

1) Capital assistance from government and other social institutions.

2) Product nata de aloe vera much preferred by the community

3) Can be innovated and developed with high creativity

d. Threat (threat)

1) Competitor

2) Quality

3) Price

4) The raw material

\section{Conclusion}

Based on the discussions described above, it can be concluded that: First, home industry producers who produce nata de aloe vera, in general, are women and housewives; this is because women and housewives mostly have spare time. Second, the existing capital is still relatively low in equipping the equipment used in processing aloe vera into nata de aloe vera. Therefore, it need help from local government and institutions. Third, the technology used in processing is still very simple and has not led to modern technology. This thing is marked by the lack of production produced by the producer of this nata de aloe vera home industry making. Fourth, the marketing aspect has yet to be optimal and still uses simple ways. It has not reached to a more sophisticated way in accordance with the development of information technology that exists today. So that they need help from related parties in terms of marketing their nata de aloe vera product. Formation of women empowerment model through entrepreneurship.

The implication of this study is to provide information about the business development strategies carried out by housewives who are the industry of the aloe vera industry in Depok and Bogor.

\section{References}

Lestari, N. (2014). The Empowerment Strategy for Small Industry in Wood Carving Craft in the Regency of Gianyar Bali. Unnud.

Natsir, N. (2013). The Effect Of Aloe Vera Leaf Extract as the Inhibitor Staphylococcus Aureus Bacterial Growth. Prosiding FMIPA Universitas Pattimura.

Novian, B. (2010). A Glimpse of Women's Empowerment. Bangka Belitung Islands: Article Studio Activities Learning Pangkalpinang City.

Resmi, G. (2014). The empowerment of poor woman through entrepreneurship development in the home industry making smoked fish in Palembang. Economic Globalization Trend \& Risk For Developing Country. 
Sanusi, A. (1994). Reviewing the potential of higher education to foster entrepreneurship program and deliver the attendance of young entrepreneurship. Bandung: Business Incubator Young.

Siswanto, B. (1989). Manpower Management, Design In Utilization and Development of Labor Elements. Bandung: Sinar Baru.

Sugiono. (2010). Educational Research Methods Quantitative Approach, Qualitative, and $R \& D$. Bandung: Alfabeta.

Sunaryanto, L. T. (2007). Study on the optimization of cluster development of small and medium enterprises (SMEs). Bases on information technology (IT) In Central Java.

Suryana. (2003). Entrepreneurship, Practical Guidance, Tips and Process to Success. Jakarta: PT. Salemba Empat.

Zimmerer, T. w. (1996). Entrepreneurship and The New Venture Formation. New Jersey: Prentice Hall Inc. 